\title{
Effects of marital breakdown on women's living conditions in Burkina Faso
}

\author{
Bilampoa Gnoumou Thiombiano \\ Institut Supérieur des Sciences de la Population (ISSP) \\ University of Ouagadougou \\ bgnoumou@issp.bf \& bilampoag@yahoo.fr \\ Bruno Schoumaker \\ Université Catholique de Louvain
}

\begin{abstract}
This study examines the effect of divorce and widowhood on women's living conditions using the data from a biographical retrospective survey. An analysis using linear regression with random intercepts showed that divorce or death of a spouse has a negative impact on women's standard of living, an effect that remains significant even in the presence of other factors and which persists over time. Young women in recent decades, rural women, and those belonging to certain ethnic groups seem to be more disadvantaged than others.
\end{abstract}

Keywords: divorce, widowhood, women's living conditions, Burkina Faso.

\section{Résumé}

Cette étude examine l'effet du divorce et du veuvage sur les conditions de vie des femmes à partir des données d'une enquête biographique rétrospective. L'analyse par la méthode de régression linéaire à effets aléatoires montre que le divorce et le veuvage ont une incidence négative sur le niveau de vie des femmes. Un effet qui demeure significatif même en présence d'autres facteurs, et qui persiste au cours du temps. Les jeunes femmes des dernières décennies, les femmes rurales et celles appartenant à certains groupes ethniques semblent davantage défavorisées que les autres. Mots-clés : divorce, veuvage, conditions de vie des femmes, Burkina Faso. 


\section{Introduction}

Several studies in Western countries indicate a deterioration in women's living conditions after a marital disruption (Burkhauser et al. 1986; Finnie 1993; Hoffman and Duncan 1998; Holden et al. 1988; Jarvis and Jenkins 1999; Li 2004; Sevak et al. 2003). These studies reveal, for example, that the death of a spouse causes a decrease in women's standard of living. Specific studies of the economic consequences of divorce also indicate negative effects on women's standard of living (Bartfeld 2000; Manting and Bouman 2006; Poortman 2000). This is probably even more the case in less developed countries such as Burkina Faso, where the husband is often the main source of family income.

However, literature on the social and economic conditions of widows and divorced women in sub-Saharan Africa is almost nonexistent. Statistical data on widowhood and divorce are very limited and lacking in detail, which may explain this situation. Anthropological studies of widowhood have been conducted on specific population groups (Attané 2005; Guyer 1985; Gwako 1998; Kaboré Konkobo 2008; Obbo 1986; Potash 1986). These studies analyzed the status of widows, widowhood rites, and the practice of levirate. Some demographic studies have also examined divorce specifically in urban Africa (Antoine and Djire 1998; Dial 2007). Studies looking at divorce and widowhood together are rare. The problem is partially addressed in studies on female heads of household, which show the economic vulnerability of households headed by women (Kebe and Charbit 2007). The specific situation of widows and divorced women, however, is poorly understood or even ignored (United Nations 2001).

According to data from Demographic and Health Surveys in Burkina Faso, widows make up 9 per cent of the female population and 0.5 per cent of women aged 45 to 49 years are divorced (INSD 2003). These data suggest a low incidence of marital breakdown, but given the frequent remarriage of young women, they do not express the magnitude of the phenomenon. To grasp its extent, we must consider the matrimonial trajectories of individuals. Analysis of biographical data in Burkina Faso shows, for example, that the level of divorce is much higher than these figures would indicate (1 union out of 10), and its frequency is increasing (Thiombiano et al. 2007).

Burkina Faso has undertaken economic reforms under structural adjustment programs since the early 1990s (Sanou 1993). These programs to restore the country's financial equilibrium have had considerable economic and social implications for the lives of individuals. People's standards of living have deteriorated, and social inequalities have also increased. Women are among those most affected by poverty. Our assumption is that widows and divorced women are most vulnerable, especially with the weakening of family and social solidarity (Calvès and Marcoux 2007).

In this study, we examine the socioeconomic consequences of marital breakdown on women's lives. Specifically, we measure the impact of union dissolution on women's living conditions, making a distinction between divorce and widowhood. We consider that in the context of Burkina Faso, where women often have low personal incomes, a union dissolution produces a decrease in their standard of living. A decrease in living standard can also be a source of tensions between spouses and result in the separation of spouses. However, longitudinal data allow 
measuring the effect of union dissolution on standard of living, while cross-sectional data would be affected by the possible reverse causation (influence of living standard on union dissolution).

In the following sections, we describe our methodology and women's marital trajectories. Then we present the results of our analysis of the effects of marital breakdown on women's standard of living. In the last section we discuss our findings and present our conclusions.

\section{Data and method}

\section{Data}

The data for this study come from a national retrospective survey, the Enquête Migration et Insertion Urbaine au Burkina (EMIUB), or Migration and Urban Integration Survey in Burkina Faso. The survey was conducted in 2000 by the International Institute for Population Sciences (ISSP) in Ouagadougou (Burkina Faso), the Demography Department of the University of Montreal and the Centre d'etudes et de recherche sur la population pour le développement (CERPOD) in Bamako (Mali). The aim of the survey was to collect information on individual life trajectories in order to analyze the interactions among the various trajectories of individual biographies and study the influence of household characteristics on demographic behaviours of individuals. The survey collected retrospective data on people's marital, migration, and occupational histories and on women's reproductive histories. Data were collected from 3,517 households comprising 22,999 people. Individual biographies were reconstructed for all household members aged 25 to 64 years and for one person out of two among those aged 15 to 24 years at the time of the survey; 8,647 individual biographies were reconstructed, including 4,685 biographies of women. For each person, the section on marital history collected information on every union (all socially recognized marriages: civil, religious, and customary) formed during the person's life. For broken unions, the end date and the type of break (divorce, widowhood) were also recorded. These data make it possible to know the marital status of women at every stage of their lives. The migration history provides information on each episode of residence lasting three months or more since the individual's sixth birthday. In addition, for each residence, this module provides data on the characteristics of housing that individuals have occupied (for details, see Poirier et al. 2001). Contrary to certain other biographical surveys conducted in urban Africa (Antoine et al. 2006), the Burkina Faso survey has the advantage of having collected data at the national level. This makes it possible to have data on individuals after their union dissolution, regardless of their place of residence.

The biographical data make it possible to follow the sequence of individual events and their interrelationships. These data make it possible to combine women's marital history with their residential history for analysis at the national level. The data file contains multiple observations on each woman regarding the number of unions and episodes of residence in her life. We used these data to study the effects of the breakdown of women's first union (divorce or widowhood) on their lives. The analysis sample comprises 3,871 women who were mar- 
ried at least once. Among them, 758 had experienced broken first unions at the time of the survey: 402 were widowed and 356 divorced.

Given that the survey was retrospective, the sample is selective to a certain degree because only women who survived death and external migration were surveyed. We assume that these women would not have behaved differently. Also, retrospective data may produce omissions that are deliberate (such as a bad marriage, for example) or involuntary (faulty memory). Nevertheless, using the "Ageevent" sheet during the survey helped improve the quality of the data collected (Antoine 2002).

\section{Method}

Linear regressions with random intercepts, which can model the evolution over time of a continuous variable, such as the index of living standards, were used for multivariate analysis. These models allowed us to observe simultaneously changes in individuals and the differences between individuals in the evolution of the phenomenon observed (Diggle et al. 1994; Singer and Willett 2003; Hedeker and Gibbons 2006). They are well suited to the analysis of biographical data, such as those used in this study, and can include independent variables that vary over time. The inclusion of random intercepts in the analysis controls for autocorrelation of the data within individuals.

The general equation of the model is as follows:

$$
Y_{i j}=\left[\beta_{00}+\beta_{10} t_{i j}+\beta_{11} t_{i j}^{2}+\beta_{12} x_{i j}+\gamma_{11} z_{i}\right]+\left[\zeta_{0 i}+\varepsilon_{i j}\right]
$$

Where $Y$ is the dependent variable, $j=1 \ldots n$ observations of the individual $i, t=a g e$ is the time of observation (predictor level 1), $x$ is an independent timevarying variable (level 1 ) and $z$ is an independent fixed variable (level 2). $\beta_{00}$ is the constant term; $\beta_{10}$ and $\beta_{11}$ are the coefficients of the age and age-squared variables, $\beta_{12}$ is the coefficient of the time varying variable, and $\gamma_{11}$ is the coefficient of a fixed variable. $\zeta_{0 i}$ represents the level-2 (individual) error term and $\varepsilon_{i j}$ is the level-1 (observation) error term. The square of these errors terms are the interindividual variance and the intraindividual variance.

These models allow us to control for correlations of observations within individuals, and to measure what proportion of the variance in the standard of living is explained by differences over time within individuals and how much is explained by differences between individuals. However, they do not allow us to use weighting in the analysis. Although the sample was not self-weighting (for instance, individuals aged 15 to 24 years at the time of the survey were under-sampled), controlling for the major variables related to sampling weights (age, area of residence, ethnicity) reduces the potential impact of not using weights. 


\section{Study Variables}

\section{Standard of living indicator}

The dependent variable of analysis is the standard of living indicator. The survey did not collect information on individuals' or households' income, but for each residence of at least three months (since age 6) for all individuals, data were collected on habitat characteristics of the households in which they lived: type of walls, roof, and floor, lighting mode, main source of drinking water, type of sanitary conveniences, and type of fuel used for cooking. But in this analysis, the information on living conditions concerns housing characteristics of households in which women lived since their first marriage. These variables are used to construct an indicator of the individual's standard of living using principal component analysis. This method of factor analysis makes it possible to reduce a set of interrelated variables (such as the housing characteristics) down to a limited number of factors or principal components. The first component (the one used here) usually explains a greater proportion of variance than the others and can be considered as the summary indicator of variables used. The process consists of applying a standardized principal component analysis for all variables made ordinal and consider the first component as the proxy of living standards. In this study, the first component, determined for each period of residence, explains 49 per cent of the variance, while the second and third components explain 13 per cent and 11 per cent, respectively. This methodology builds on previous work that used data on housing to construct indicators (Filmer and Pritchett 2001; Kobiané 2004; Kobiané et al. 2005; Montgomery 2000). All variables used in the creation of the indicator change over time. So, this indicator measures the standard of living of individuals at every moment of their lives and is suited to the analysis models we used. The indicator varies between 4.79 and 19.78 (5.14 and 18.97 for divorced women and widows), and its average is 8.74 for all women.

This indicator, which is in fact an index of housing comfort, is not a perfect reflection of the socioeconomic situation of individuals. It concerns the household, but not everyone in the household has the same status. For example, a person being housed there does not have the same living conditions as the head of household, but the data on housing collected in the surveys often relates to the residence of the head of household. Furthermore, when a widow remains in the same dwelling after the death of her spouse, the habitat characteristics do not change much, and the indicator hardly changes, but she can experience a marked deterioration in her living standards. Still, this indicator is a nonmonetary measure that reflects households' socioeconomic standard of living fairly well (Filmer and Pritchett 2001; Kobiané 2004) and, indirectly, that of the household members.

\section{Independent variables}

The main independent variable is the marital status of women. On the assumption that the effect of marital breakdown on women's standard of living changes over time, we subdivided the divorced and widowed categories according to the duration in the status: less than a year, one to four years, and five years or more. The married category includes all married women whatever the duration of marriage. 
We also used in the models a number of control variables that are known to influence the standard of living: age and age squared, education, religion, ethnicity, occupational status, area of residence, and period of observation. Marital status, age, occupational status, period and area of residence are time-varying variables; the rest (education, religion, and ethnicity) are fixed. Area of residence has three categories: urban, rural, and outside the country. The period variable, which allows us to observe the effect of socioeconomic and political developments on the evolution of living standards, is subdivided into two: the period before 1990 and the period 1990-2000, which was marked by structural adjustment programs (Burkina Faso has undertaken structural adjustment programs since 1990). A woman can appear in both periods, according to the time she spends in the population at risk. Independent variables are presented in the next section. The variables religion and ethnicity play an important social role in Burkina Faso, and may also be linked to differences in standard of living and marital breakdowns. It is thus important to control them in the models.

\section{Results}

\section{Marital trajectories of women}

In Burkina Faso, as in many African countries, being married confers respect and consideration upon women. About 3,871 (83 per cent) of the 4,685 women had been married in their lifetime. Among them, about 13 per cent had formed a second marriage and only one in 100 lived in a third union. The average age at first marriage for women was 17 years, but 15 per cent were married early, before age 15. This finding confirms the frequency of early marriage and more generally that of marriage for women.

Figure 1 represents the marital trajectories of women. A married woman may remain in a union, or the union may be broken by divorce or widowhood. The solid arrows describe women's marital trajectories, and dotted arrows represent women who remain in the same status. The numbers represent the number of women in each state. The results show that widows remarry less often than do divorcees. Only 190 widows of 402 have remarried, against 310 of 356 divorcees. Divorce often occurs at a younger age than widowhood, which facilitates the remarriage of divorced women. In a society where the primary aim of marriage is procreation, a woman of infertile age is less likely to remarry. In addition, the second marriage seems more stable for divorced women (85 per cent remain remarried) than for widows (79 per cent remain remarried). Among the 3,871 women in the sample, only 43 had a third union (results not shown).

\section{Descriptive statistics}

In this section, we present sample characteristics and women's marital trajectories and family status. The population likely to experience these events consists of women between the ages of 15 and 64 years having been in a union at least once in their lives. Table 1 presents characteristics of women computed on the person-year data set used in the multivariate analyses. It includes all the years starting from the first marriage, and measures the percentage of person-years in each 


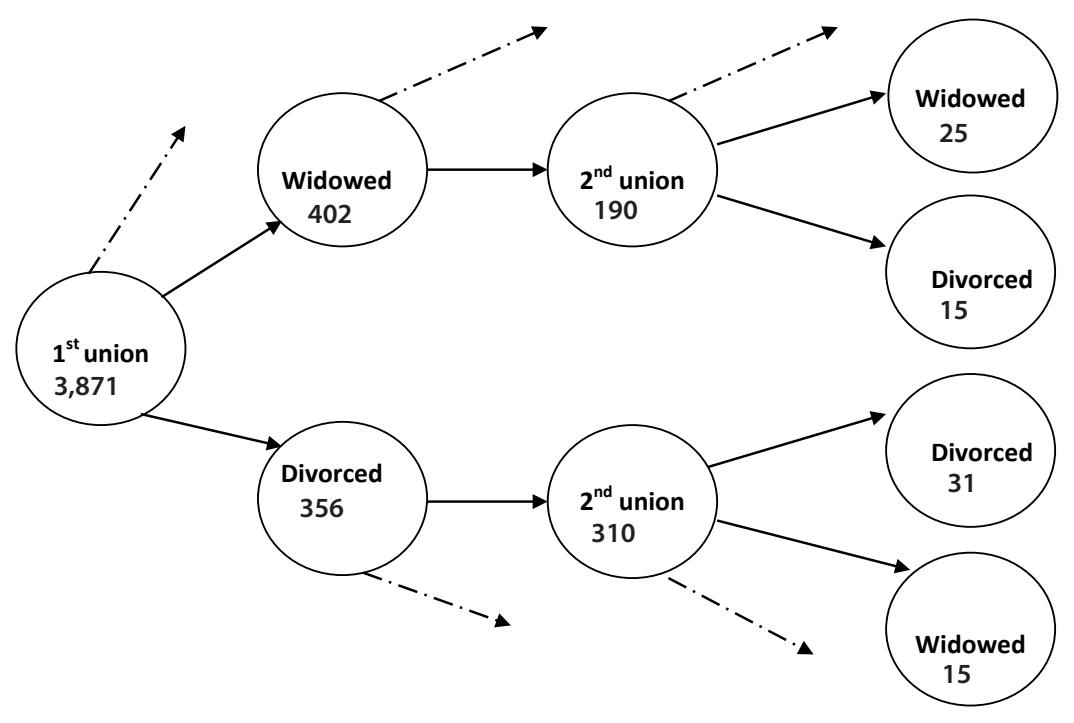

Figure 1. Marital itinerary of women.

category of the analysis sample. The majority of the women are uneducated and living in rural areas. The data also represent the ethnic and religious diversity of the population of Burkina Faso. About half of women are of the Mossi ethnic group, and half of them are Muslim. Most of them are either self-employed or staying at home.

\section{Women's family situation}

Using household data, we consider the relationship to head of household to observe women's family situation and indirectly who support them. Analysis of the women's relationship with the household head shows that over 80 per cent of widows and divorced women at the time of the survey were supported by a relative (Table 2). Widows were primarily supported by their children (66 per cent of widows), while divorcees were supported by siblings (23 per cent) and parents (30 per cent). In Burkina Faso, there is virtually no system of formal social protection, and only employees receive a retirement pension. In this context, children are old-age insurance for parents. Widows who have economically active children are often supported by them. Young divorcees often return to live in their family of origin while waiting to remarry. The others ( 20 per cent of widows and 17 per cent of divorced women) are compelled to become the head of their household.

However, these findings are to be considered with caution. For example, divorced women and widows may declare a male relative, who gave them no economic support, as head of their household. The proportion of widows and divorcees who are actually the head of their household is probably underestimated by these data. The current economic crisis and impoverishment of people seems to seriously undermine family solidarity. The weakening of families' economic power could call this social value into question and reduce aid to vulnerable people. 
Table 1. Distribution of women by sociodemographic characteristics (person-years).

\begin{tabular}{|c|c|}
\hline Variable & $\begin{array}{l}\text { Number of person-years } \\
\text { lived (weighted percentages) }\end{array}$ \\
\hline \multicolumn{2}{|l|}{ Status of first union (v) } \\
\hline Married & 87.8 \\
\hline Divorced & 2.2 \\
\hline Widowed & 10.0 \\
\hline \multicolumn{2}{|l|}{ Age group (v) } \\
\hline $15-24$ years & 72.5 \\
\hline $25-34$ years & 19.6 \\
\hline 35 years + & 7.9 \\
\hline \multicolumn{2}{|l|}{ Period (v) } \\
\hline Before 1990 & 76.5 \\
\hline 1990-2000 & 23.5 \\
\hline \multicolumn{2}{|l|}{ Education } \\
\hline None & 92.7 \\
\hline Primary education & 5.7 \\
\hline Secondary education+ & 1.6 \\
\hline \multicolumn{2}{|l|}{ Religion } \\
\hline Animist & 29.8 \\
\hline Muslim & 51.2 \\
\hline Christian & 18.8 \\
\hline Other & 0.2 \\
\hline \multicolumn{2}{|l|}{ Ethnicity } \\
\hline Mossi & 47.3 \\
\hline Gourmantché & 6.5 \\
\hline Fulani & 7.9 \\
\hline Gourounsi & 6.0 \\
\hline Bobo-Bwa & 5.0 \\
\hline Lobi-Dagari & 7.8 \\
\hline Other & 19.4 \\
\hline \multicolumn{2}{|l|}{ Occupational status (v) } \\
\hline Independent worker & 54.8 \\
\hline Employee & 1.2 \\
\hline $\begin{array}{l}\text { Apprentice/domestic/ } \\
\text { at home }\end{array}$ & 43.8 \\
\hline Other & 0.2 \\
\hline \multicolumn{2}{|l|}{ Area of residence (v) } \\
\hline Rural & 86.0 \\
\hline Urban & 8.2 \\
\hline Foreigner & 5.8 \\
\hline Total & $73,754.0$ \\
\hline
\end{tabular}

(v): Variables whose value can change over time.

\section{Multivariate analysis results}

Table 3 presents results from three linear regression models with random intercepts. The first model measures the unconditional average. The results indicate that over 91 per cent of the total variance in the standard of living is attributable to differences among women, and the rest is attributable to changes within individuals. The large and significant inter-individual (level-2) variance confirms the adequacy of using a random intercepts model. The second model estimates the effect of union dissolution on standard of living, controlling only for the dur- 
Table 2. Women's family situation (relationship with the head of household).

\begin{tabular}{lrrrrrr}
\hline \multirow{2}{*}{ Status in the household } & \multicolumn{2}{c}{ Married } & \multicolumn{2}{c}{ Widowed } & \multicolumn{2}{c}{ Divorced } \\
\cline { 2 - 7 } & \multicolumn{1}{c}{ N } & Per cent & N & Per cent & N & Per cent \\
\hline Head of household & 72.1 & 1.5 & 93.1 & 19.2 & 12.8 & 17.2 \\
Spouse & $3,730.9$ & 78.7 & 0.0 & 0.0 & 0.0 & 0.0 \\
Mother / Stepmother & 820.4 & 17.3 & 322.0 & 66.3 & 9.6 & 12.9 \\
Brother / Sister & 17.0 & 0.4 & 11.8 & 2.4 & 17.0 & 22.9 \\
Son / Daughter & 36.2 & 0.8 & 4.3 & 0.9 & 21.9 & 29.5 \\
Other relatives & 61.6 & 1.3 & 54.3 & 11.2 & 13.0 & 17.5 \\
\hline Total & $4,738.1$ & 100.0 & 485.5 & 100.0 & 74.4 & 100.0 \\
\hline
\end{tabular}

ation variable (age and age squared). Finally, the third model controls the influence of additional independent variables on women's standard of living. The effects of the explanatory variables are expressed as differences relative to the reference category omitted from the model.

\section{Effects of divorce and widowhood on women's standard of living}

Our findings show that divorce and widowhood have a negative impact on women's standard of living. As we originally posited, divorce and widowhood significantly reduced women's standard of living, both in model 2 and model 3. Although there are some differences in the coefficients of union dissolution between these two models, their comparison shows that controlling for additional variables does not modify the results in a substantial way. For this reason, only results of model 3 will be discussed.

The negative effect of divorce is statistically significant $(p<0.001)^{1}$ and becomes much more pronounced one year after separation. However, from the fifth year after divorce, this negative effect remains but is less pronounced. This finding can probably be explained by women's coping strategies after divorce. During the first year after divorce, women often return to live with their family of origin pending a possible reconciliation with their husband or a remarriage. However, the chances of these occurring decline with time. For parents, maintaining a divorced woman in the family confers a bad reputation and sets a "bad example" for young unmarried sisters. Also, the difficulty of cohabiting with parents may force divorcees to become economically independent and their standard of living may deteriorate at that time. But the results show that they are able to reduce this negative effect later.

The negative effect of widowhood is also important in the first year, and decreases markedly after five years. In the past, the traditional system of social and family solidarity could take care of widows and orphans. For example, in patrilineal societies, the widow remained the property of her late husband's family or lineage. According to some customs (e.g., the Mossi of Burkina Faso), she is part of the legacy bequeathed by her husband (for more details on the practice of levirate among the Mossi, see Kaboré Konkobo 2008). Levirate or remarriage of the widow to her late husband's relative (brother, son of another wife, etc.) reflects the fact that the woman belongs to her in-laws. The new spouse has an obligation

1. Its magnitude is similar to differences by employment status. The decrease of standard of living associated with divorce is about one fifth of the standard deviation of intraindividual differences (square root of intraindividual variance). 
to support the widow and orphans. This practice, also common in other ethnic groups, such as Maragoli Kenya (Gwako 1998), ensures continuity of lineage. The children of the remarriage have, in principle, the same social status in the family as the children of the first marriage. Currently, it seems widows benefit very little from such family solidarity.

Women are also sometimes victims of expropriation of assets from their household. In the case of divorce, for example, it is often the husband who retains the property acquired during marriage. The legacy of a deceased spouse is also frequently shared among members of the extended family at the widow's expense. Writing a will is not a common practice in Burkina Faso, and traditionally women do not inherit from their husbands; hence, the expropriation of assets. It even happens that the family seeks custody of the children in order to gain the inheritance. Yet, according to the Code on the Individual and the Family (articles 514,515 , and 519), in the case of a parent's death, the surviving parent normally exercises parental authority (Burkina Faso 1990).

Interestingly, our findings show that women's standard of living increases with age (and age ${ }^{2}$ ), suggesting that the effect of marital breakdown on the standard of living may be somewhat mitigated for older women. They are more likely to have economically active children on whom they can depend. As stated above in the descriptive results, children are old-age insurance for parents. Conversely, young women are sometimes very economically insecure. This is probably the case for women who divorce or become widowed at a young age.

\section{Effect of other variables on the standard of living}

Several other variables also have significant effects on women's standard of living. The variable of ethnicity, indicating an individual's membership in a social group, introduces significant differences among women. Women of the Gourounsi, Fulani, Lobi-Dagara, Bobo-Bwa and Gourmantché groups are associated with low standards of living compared to Mossi women.

These differences may have several explanations. Mossi society is hierarchical, with centralized authority, while for example Bobo-Bwa groups have a more liberal social organization. Thus, unlike the Mossi group where the husband generally provides for all the food needs of the household from the products of collective fields, Bobo-Bwa women support some of these needs (Dacher 1992). This social organization partly determines the economic power of women (Kobiané 2007). These differences might also be explained by the type of habitat. The Fulani nomads often have precarious habitats compared to Mossi, who are sedentary.

Moreover, rural women are associated with lower standards of living than women in urban areas. This result may be related partly to the nature of the indicator used. Home comfort is generally higher in cities than in the countryside. As expected, women with secondary and higher education are associated with a much higher standard of living than those having only primary school. These women are often employed, and as indicated by the results, employed women have slightly higher standards of living. Conversely, uneducated women have a much lower standard of living than those with primary school. Animist women also have lower standard of living than the Muslim, but the difference between Christian and Muslim women is not significant. 
Table 3. Estimated impact of explanatory variables on women's standard of living (results of linear regression models with random intercepts).

\begin{tabular}{|c|c|c|c|}
\hline Variable & Model 1 & Model 2 & Model 3 \\
\hline \multicolumn{4}{|l|}{ Fixed effects } \\
\hline Constant $\left(\gamma_{00}\right)$ & $10.628 * * *$ & $9.327 * * *$ & $13.492 * * *$ \\
\hline Age (continuous) & & $0.072 * * *$ & $0.018 * * *$ \\
\hline age squared $(/ 10)$ & & $0.004 * * *$ & 0.000 \\
\hline \multicolumn{4}{|l|}{ Marital status ${ }^{(\mathrm{v})}$ (Married) } \\
\hline Divorced $<1$ year & & $-0.201 * * *$ & $-0.184 * * *$ \\
\hline Divorced $1-4$ years & & $-0.175^{* * *}$ & $-0.229 * * *$ \\
\hline Divorced $5+$ years & & -0.025 & $-0.188 * * *$ \\
\hline Widow $<1$ year & & $-0.093 *$ & $-0.135 * * *$ \\
\hline Widow $1-4$ years & & -0.016 & $-0.115^{* * *}$ \\
\hline Widow 5+ years & & $-0.93 * *$ & $-0.086^{* *}$ \\
\hline \multicolumn{4}{|l|}{ Period $^{(v)}$ (before 1990) } \\
\hline 1990-2000 & & & 0.024 \\
\hline \multicolumn{4}{|l|}{ Education (Primary) } \\
\hline Secondary and higher & & & $1.856^{* * *}$ \\
\hline None & & & $-2.003 * * *$ \\
\hline \multicolumn{4}{|l|}{ Religion (Muslim) } \\
\hline Animist & & & $-1.516^{* * *}$ \\
\hline Christian & & & 0.067 \\
\hline Other & & & -0.070 \\
\hline \multicolumn{4}{|l|}{ Ethnicity (Mossi) } \\
\hline Gourmantché & & & $-1.826^{* * *}$ \\
\hline Fulani & & & $-2.126^{* * *}$ \\
\hline Gourounsi & & & $-0.724 * * *$ \\
\hline Bobo-Bwa & & & -0.082 \\
\hline Lobi-Dagara & & & -0.232 \\
\hline Other & & & 0.033 \\
\hline \multicolumn{4}{|l|}{ Occupational status (Independent) } \\
\hline Employee & & & $0.264 * * *$ \\
\hline Apprentice / domestic & & & $-0.231 * * *$ \\
\hline Other & & & 0.001 \\
\hline \multicolumn{4}{|l|}{ Area of residence ${ }^{(v)}$ (Urban) } \\
\hline Rural & & & $-1.572 * * *$ \\
\hline Foreigner & & & $-2.246 * * *$ \\
\hline \multicolumn{4}{|l|}{ Random effects } \\
\hline Residual interindividual variance $\left(\sigma_{0}^{2}\right)$ & $9.426 * * *$ & $9.129 * * *$ & $3.678 * * *$ \\
\hline Residual intraindividual variance $\left(\sigma_{\varepsilon}^{2}\right)$ & $0.906 * * *$ & $0.824 * * *$ & $0.703 * * *$ \\
\hline$\hat{\rho}$ & 0.912 & 0.917 & 0.839 \\
\hline Number of observations & 9,509 & 9,509 & 9,509 \\
\hline Number of individuals & 3,871 & 3,871 & 3,871 \\
\hline
\end{tabular}

$* \mathrm{p}<0.05 ; * * \mathrm{p}<0.01 ; * * * \mathrm{p}<0.001$. Reference category in brackets.

(v): Variables whose value can change over time.

$\hat{\rho}$ : Proportion of the total variance of the standard of living due to differences between women, obtained by dividing 


\section{Conclusion}

We have used biographical data to observe the effects of marital breakdown on women's lives. Analysis produced several interesting and original results, especially in the study context. Multivariate analysis showed a significant negative impact of divorce and widowhood on women's standard of living. The analyses confirm our hypothesis and are in line with other studies (Corcoran 1979; Weir et al. 2002). Divorce or death of a spouse significantly lowered women's standard of living. This negative effect remains significant even in the presence of other factors. We thought this negative effect might diminish or even disappear with time. We supposed that women out of unions could, over time, become better organized to improve their living conditions. However, our findings show that women's standard of living begins to deteriorate at the time of the dissolution of the union and that this situation persists even five years later.

In addition to economic hardship, women can also suffer from a lack of personal security and social protection. In general, marriage provides social security for women because the husband feels obligated to protect his wife. In cases of separation, women lose that security. For example, divorced women sometimes lived in isolation, abandoned by family and friends (Thiombiano 2009).

These results could be indicative of economic and social change underway in African societies, as reported in recent studies (Adjamagbo 1997; Calvès and Marcoux 2007). For example, traditionally in patrilineal societies, the husband's family had a duty to take care of widows and orphans. A divorced woman could also live with her family of origin while waiting to remarry. Family solidarity compensated for the absence of formal systems of social assistance. But this solidarity seems to have been weakened by the current economic crisis and the implementation of structural adjustment programs. By impoverishing households, the crisis has reduced their ability to provide mutual assistance. The modernization of society and adoption of new lifestyles has also had a negative impact on this social value. For example, the urban lifestyle with restricted housing space is not conducive to accommodating members of the extended family.

In agricultural societies, children frequently support their parents, confirming their economic role. Widows, sometimes old, enjoy the benefit of having active children on whom they can rely. However, women with young children (and those with none) sometimes lack support and suffer more after marital breakdown. They must organize themselves to support their children, and their standard of living may decline substantially.

The results of our study support the inclusion of specific groups such as widows and divorcees in studies on the status of women in sub-Saharan Africa and in national population policies. More useful data-with, for example, information on the care of children after marital breakdown — is required to study the deterioration of living conditions of widows and divorcees in greater depth. 


\section{References}

Adjamagbo, A. 1997. Les solidarités familiales dans les sociétés d'économie de plantation: Le cas de la région de Sassandra en Côte d'Ivoire, in Ménages et familles en Afrique: Approches des dynamiques contemporaines, edited by M. Pilon, T. Locoh, É. Vignikin, and P. Vimard. Paris: CEPED, pp. 301-25.

Antoine, P. 2002. L'approche biographique de la nuptialité: Application à l'Afrique, in Démographie: Analyse et synthèse II. Les déterminants de la fécondité, edited by G. Caselli, J. Vallin, and G. Wunsch, eds. Paris: INED, pp. 51-74.

- 2006. Analyse biographique de la transformation des modèles matrimoniaux dans quatre capitales africaines: Antananarivo, Dakar, Lomé et Yaoundé. Cabier québécois de démographie 35(2):5-38.

Antoine, P. and M. Djire. 1998. Crise et évolution des comportements matrimoniaux à Dakar, in Crises, pauvreté et changements démographiques dans les pays du sud, edited by F. Gendreau. Paris: AUPELF-UREF, Éditions ESTEM, pp. 203-35.

Attané, A. 2005. Statuts des veuves et rituels de veuvage en Afrique de l'Ouest : Revue critique des connaissances anthropologiques. Paper presented at the XXV IUSSP International Population Conference, Tours, France, July 18-23, 2005.

Bartfeld, J. 2000. Child support and the postdivorce economic well-being of mothers, fathers, and children. Demography 37(2):203-13.

Burkhauser, R., K.C. Holden, and D.A. Myers. 1986. Marital disruption and poverty: The role of survey procedures in artificially creating poverty. Demography 23(4):621-31.

Burkina Faso. 1990. Code des personnes et de la famille. Ouagadougou: Government of Burkina Faso.

Calvès, A. and R. Marcoux. 2007. Les processus d'individualisation 'à l'africaine', in Sociologie et Société. Vol. 39(2), Sociétés africaines en mutation: Entre individualisme et communautarisme / Mutating African Societies: Between Individualism and Communitarism, edited by A. Calvès and R. Marcoux, pp. 5-18.

Corcoran, M. 1979. The economic consequences of marital dissolution for women in the middle years. Sex Roles 5(3):343-53.

Dacher, M. 1992. Prix des épouses, valeurs des scurs, suivi de: Les représentations de la maladie. Deux études sur la société goin (Burkina Faso). Paris: L'Harmattan.

Dial, F.B. 2007. Le divorce, une source d'émancipation pour les femmes? Une enquête à Dakar et Saint-Louis, in Genre et sociétés en Afrique. Implications pour le développement, edited by T. Locoh. Paris: INED, pp. 357-72.

Diggle, J.P., K.-Y. Liang, and S.L. Zeger. 1994. Analysis of Longitudinal Data. Oxford: Oxford University Press.

Filmer, D. and L.H. Pritchett 2001. Estimating wealth effects without expenditure dataor tears: An application to educational enrollments in states of India. Demography 38:115-32.

Finnie, R. 1993. Women, men, and economic consequences of divorce: Evidence from Canadian longitudinal data. Canadian Review of Sociology and Anthropology 30(2):205-41.

Guyer, I.J. 1985. The economic position of Beti widows past and present, in Femmes du Cameroun: Mères pacifiques, femmes rebelles, edited by J.-C. Barbier. Paris: KarthalaORSTOM, pp. 313-25.

Gwako, E.L.M. 1998. Widow inheritance among the Maragoli of western Kenya. Journal of Anthropological Research 54(2):173-98.

Hedeker, D. and R.D. Gibbons. 2006. Longitudinal Data Analysis. Hoboken, NJ: John Wiley \& Sons.

Hoffman, S.D. and G.J. Duncan. 1998. What are the economic consequences of divorce? Demography 25(4):641-5.

Holden, C.K., R. Burkhauser, and D.J. Feaster. 1988. The timing of falls into poverty after retirement and widowhood. Demography 25(3):405-14. 
INSD (Institut national de la statistique et de la démographie). 2003. Enquête démographique et de santé, Burkina Faso, 2003. Ouagadougou and Calverton MD: Macro International.

Jarvis, S. and S.P. Jenkins. 1999. Marital splits and income changes: Evidence from the British household panel survey. Population Studies 53(2):237-54.

Kaboré Konkobo, M. 2008. Le lévirat face à l'impact du VIH/SIDA au Burkina Faso : Cas de la société moaaga. Women Health Education Programme, education and teaching materials. Paris: WHEP.

Kebe, M. and Y. Charbit. 2007. Genre et vulnérabilité au Sénégal : Les femmes chefs de ménage. Revue européenne des migrations internationales 23(3):51-65.

Kobiané, J.-F. 2004. Habitat et biens d'équipement comme indicateurs de niveau de vie des ménages: Bilan méthodologique et application à la relation pauvreté-scolarisation. Étude de la Population Africaine 19(suppl A):265-83.

2007. Ethnie, genre et scolarisation au Burkina Faso, in Genre et sociétés en Afrique: Implications pour le développement, edited by T. Locoh. Paris: INED, pp. 221-41.

Kobiané, J.-F., A.-E. Calves, and R. Marcoux. 2005. Parental death and children's schooling in Burkina Faso. Comparative Education Review 49(4):468-89.

Li, C. 2004. Widowhood: Consequences on income for senior women. Analysis document no. 15, catalog no. 11-621-MIE2004015. Ottawa: Statistics Canada.

Manting, D. and A.M. Bouman. 2006. Short-and long-term economic consequences of the dissolution of marital and consensual unions: The example of the Netherlands. European Sociological Review 22(4):413-29.

Montgomery, M.R. 2000. Measuring living standards with proxy variables. Demography 37(2): 155-74.

Obbo, C. 1986. Some East African widows, in Widows in African Societies: Choices and Constraints, edited by B. Potash. Stanford, CA: Stanford University Press, pp. 84-106.

Poirier, J., V. Piché, G. Le Jeune, B. Dabiré, and H.R. Wane. 2001. Projet d'étude des stratégies de reproduction des populations sahéliennes à partir de l'enquête 'Dynamique migratoire, insertion urbaine et environnement au Burkina Faso'. Cahiers québécois de démographie 30(2):289-309.

Poortman, A.-R. 2000. Sex differences in the economic consequences of separation. A panel study of the Netherlands. European Sociological Review 16(4):367-84.

Potash, B. 1986. Widows in Africa: An introduction, in Widows in African Societies: Choices and Constraints, edited by B. Potash. Stanford, CA: Stanford University Press, pp. $1-43$.

Sanou, O.M. 1993. Pauvreté et marché du travail à Ouagadougou (Burkina Faso). Institut international d'études sociales, discussion paper DP/57/1993. Geneva: IIES.

Sevak, P, D.R. Weir, and R.J. Willis. 2003. The economic consequences of a husband's death: Evidence from the HRS and AHEAD. Social Security Bulletin 65(3):31-44.

Singer, D.J. and J.B. Willet. 2003. Applied Longitudinal Data Analysis: Modeling Change and Event Occurrence. Oxford: Oxford University Press.

Thiombiano, B. 2009. Rupture d'unions conjugales au Burkina Faso: Causes et effets sur les femmes et leurs enfants. PhD thesis, Dept. of Demography, Univ. de Montréal.

Thiombiano, B., T. LeGrand, and B.D. Schoumaker. 2007. Niveau, tendance et facteurs d'instabilité des unions au Burkina Faso: Une analyse à partir de biographies individuelles et communautaires. Paper presented at the Fifth African Population Conference, Arusha, Tanzania. UEPA. December 10-14, 2007.

United Nations (UN Division for the Advancement of Women). 2001. Widowhood: Invisible women, secluded or excluded. Women 2000 December:2-19.

Weir, R.D., R.J. Willis, and P. Sevak. 2002. The economic consequences of a husband's death: Evidence from the HRS and AHEAD. Paper presented at the Second Annual Joint Conference for the Retirement Research Consortium "The Outlook for Retirement Income,” Washington, DC, May 17-18, 2002. 